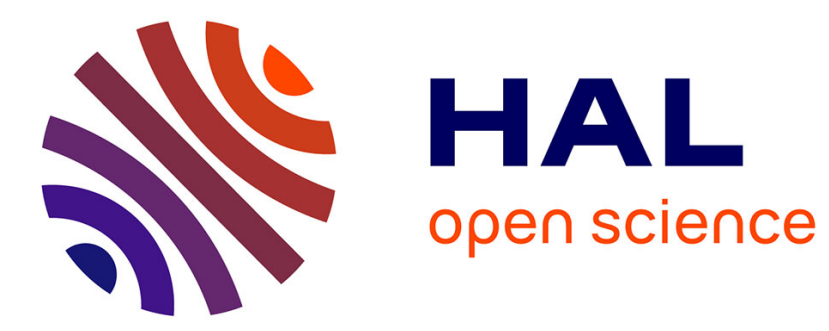

\title{
From Formal Subsumption to General Intellect: Elements for a Marxist Reading of the Thesis of Cognitive Capitalism, in Historical Materialism
}

\author{
Carlo Vercellone
}

\section{To cite this version: \\ Carlo Vercellone. From Formal Subsumption to General Intellect: Elements for a Marxist Reading of the Thesis of Cognitive Capitalism, in Historical Materialism. Historical Materialism, 2007, 15 (1), pp.13-36. 10.1163/156920607X171681 . halshs-00263661}

\section{HAL Id: halshs-00263661 \\ https://shs.hal.science/halshs-00263661}

Submitted on 14 Mar 2008

HAL is a multi-disciplinary open access archive for the deposit and dissemination of scientific research documents, whether they are published or not. The documents may come from teaching and research institutions in France or abroad, or from public or private research centers.
L'archive ouverte pluridisciplinaire HAL, est destinée au dépôt et à la diffusion de documents scientifiques de niveau recherche, publiés ou non, émanant des établissements d'enseignement et de recherche français ou étrangers, des laboratoires publics ou privés. 


\title{
From Formal Subsumption to General Intellect: Elements for a Marxist Reading of the Thesis of Cognitive Capitalism
}

\author{
Carlo Vercellone \\ Lecturer of economics, University of Paris I Panthéon-Sorbonne, France. \\ Carlo.Vercellone@univ-paris1.fr
}

\begin{abstract}
Since the crisis of Fordism, capitalism has been characterised by the ever more central role of knowledge and the rise of the cognitive dimensions of labour. This is not to say that the centrality of knowledge to capitalism is new per se. Rather, the question we must ask is to what extent we can speak of a new role for knowledge and, more importantly, its relationship with transformations in the capital/labour relation. From this perspective, the paper highlights the continuing validity of Marx's analysis of the knowledge/power relation in the development of the division of labour. More precisely, we are concerned with the theoretical and heuristic value of the concepts of formal subsumption, real subsumption and general intellect for any interpretation of the present change of the capital/labour relation in cognitive capitalism. In this way, we show the originality of the general intellect hypothesis as a sublation of real subsumption. Finally, the article summarises key contradictions and new forms of antagonism in cognitive capitalism.
\end{abstract}

\section{Keywords}

crisis, division of labour, knowledge, formal subsumption, real subsumption, general intellect, cognitive capitalism, diffuse intellectuality

\section{Introduction}

The contemporary historical conjuncture is marked by the diffusion and the evermore central role of knowledge in the organisation of production and the dynamic of technical progress. ${ }^{1}$ This evolution is accounted for by neoclassical theories of endogenous growth and of a knowledge-based economy through an approach which abstracts from the capital/labour antagonism and from the

1. I would like to thank the referees for their critical suggestions that have allowed me to develop and clarify the ideas presented here. 
conflicts of knowledge and power which structure transformations in the division of labour. ${ }^{2}$

The hypothesis of cognitive capitalism develops from a critique of the political economy of the new liberal theories of the knowledge-based economy. An understanding of the meaning at stake in the current mutation of capitalism cannot be reduced to the mere constitution of an economy founded on knowledge, but in the formation of a knowledge-based economy framed and subsumed by the laws of capital accumulation. ${ }^{3}$

On this basis, this article investigates two theoretical questions to which we will attempt to give some of the elements of a response. Does the tendency to the diffusion of knowledge signal a break with respect to the logic of the capitalist division of labour and of technical progress operative since the first industrial

2. For a critique of these theories, see Lebert and Vercellone 2004.

3. This critical perspective on apologetic accounts of neoliberal inspiration is inscribed in the two terms which compose the very concept of cognitive capitalism: i) the notion of 'capitalism' defines the enduring element in the change of the structural invariants of the capitalist mode of production: in particular, the driving role of profit and the wage relation or, more precisely, the different forms of dependent labour on which the extraction of surplus labour is founded; ii) the term 'cognitive' emphasises the new nature of the conflictual relation of capital and labour, and of the forms of property on which the accumulation of capital rests. It is necessary to note that the notion of cognitive capitalism has also been developed as a response to the insufficiency of the interpretations of the current mutation of capitalism in terms of the transition from a Fordist to a post-Fordist model of flexible, or what is sometimes referred to as 'Toyota-ist', accumulation. The interpretative category of 'post-Fordism', adopted by both a critical Left coming from workerism [operaismo] and by economists of the regulation school, essentially remains a prisoner of a neoindustrialist vision of the new capitalism. The new model of production and the new nature of the relation of capital to labour are conceived principally as an immanent overcoming of the socioeconomic factors which have brought to an end the rigid paradigm of mass production. In substance, for the theories of post-Fordism, the first aspect of the new productive model can be traced back to the technological leap of telematic and microelectronic innovation that occurred with the third industrial revolution. The argument goes that the association of the information revolution and Japanese methods of lean production have allowed the old assembly line to adapt to the increasingly unstable and volatile nature of demand. At the same time, thanks to a new organisation of labour in terms that are more flexible and decentralised, the new model of production is said to have eliminated the critical points of the cycle of production upon which the emergence of the antagonistic figure of the mass worker was founded. Theories of post-Fordism, while capturing some significant elements of rupture, often remain bound to a factory-inspired vision of the new capitalism seen as a further development of the Fordist-industrial logic of the real subsumption of labour by capital. For these reasons, the category of post-Fordism appears to us to be inadequate for comprehending the profound transformation of the antagonistic relation of capital to labour related to the development of an economy founded on the driving role of knowledge and the figure of the collective worker of the general intellect. The notion of cognitive capitalism aims to contribute to overcoming these difficulties, taking account of the way in which the crisis of Fordism has corresponded to a superior level of 'great crisis'. This crisis signals the exhaustion not only of a model of development specific to industrial capitalism but the tendential crisis of some of the more structural invariants of the long-period dynamic that opened with the first industrial revolution. 
revolution? To what degree is it possible to find in Marx and, in particular, in the notion of the general intellect, elements that allow for the identification of the radically new character of the contradictions and of the antagonism that traverses cognitive capitalism?

In order to respond to these questions, this article proposes to highlight the originality and the actuality of Marx's contribution, underlining the conflictual relation of knowledge to power that determines the development of the capitalist division of labour. Specifically, we will deal with the theoretical and heuristic value of the concepts of formal subsumption, real subsumption and the general intellect. The notion of subsumption ${ }^{4}$ is used by Marx to characterise the differing forms of subordination of labour to capital. With the idea of the general intellect, he designates a radical change of the subsumption of labour to capital and indicates a third stage of the division of labour. It involves a tendential overcoming of the Smithian logic of the division of labour proper to industrial capitalism, and posits, in a new manner with respect to the other writings of Marx, the possibility of a direct transition to communism.

We shall see that these categories are useful in crafting a theoretical reconstruction in historical time which is able to identify the significance of the current turning point in the dynamic of capitalism in the longue durée. From this results a periodisation in which three principal stages of the capitalist division of labour and of the role of knowledge can be identified (even if these phases in part overlap with each other). ${ }^{5}$

i) The stage of formal subsumption develops between the beginning of the sixteenth and the end of the eighteenth century. It is based on the models of production of the putting-out system ${ }^{6}$ and of centralised manufacture. The relation of capital/labour is marked by the hegemony of the knowledge of craftsmen and of workers with a trade, and by the pre-eminence of the mechanisms of accumulation of a mercantile and financial type.

4. I have preferred the term 'subsumption' to 'submission' because it better allows us to grasp the permanence of the opposition of capital to labour and the conflict for the control of the intellectual powers of production' in the unfolding of the different stages of the capitalist division of labour.

5. The periodisation that I propose here is essentially aimed at showing the relevance and heuristic value of Marxian categories and method for any interpretation of the present mutation of the capital/labour relation. Therefore, I privilege an analysis centred on the development of tendencies and ruptures within the Marxian discourse, even if this is to the detriment of a more detailed historical argument. For a more developed historical perspective on the complexity of the processes that led from industrial capitalism to cognitive capitalism, I suggest that the reader see Lebert and Vercellone 2003 and Vercellone 1999, 2003a, 2004, 2006 and Vercellone (ed.) 2003.

6. This system, also called the system of the diffuse factory, is based on the figure of the mercantile entrepreneur who organises production in the home by artisans and independent workers. 
ii) The stage of real subsumption starts with the first industrial revolution. The division of labour is characterised by a process of polarisation of knowledge which is expressed in the parcelling out and disqualification of the labour of execution and in the overqualification of a minoritarian component of labourpower, destined to intellectual functions. ${ }^{7}$ The attempt to save time, founded on the law of value-labour, is accompanied by the reduction of complex labour into simple labour and by the incorporation of knowledge in fixed capital and in the organisation of the firm. The dynamic of capital accumulation is founded on the large factories (first of all, those of the Mancunian model, then those of Fordism), which are specialised in the production of mass, standardised goods.

iii) The third stage is that of cognitive capitalism. It begins with the social crisis of Fordism and of the Smithian division of labour. The relation of capital to labour is marked by the hegemony of knowledges, by a diffuse intellectuality, and by the driving role of the production of knowledges by means of knowledges connected to the increasingly immaterial and cognitive character of labour. ${ }^{8}$ This new phase of the division of labour is accompanied by the crisis of the law of value-labour and by the strong return of mercantile and financial mechanisms of accumulation. The principal elements of this new configuration of capitalism and of the conflicts that derive from it are, in large measure, anticipated by Marx's notion of the general intellect.

\section{Formal subsumption, real subsumption and general intellect: an historical perspective on the transformations of the division of labour}

\section{Division of labour and relations of knowledge/power. First and fundamental terrain of the conflicts between capital and labour.}

Marx's approach continues to offer an interpretative paradigm that helps us account not only for the transformations of the division of labour but also for the trajectories which could create, to use a phrase from Schumpeter, 'the conditions of a new evolution'. Marx's analysis constitutes, from a methodological point of view, one of the first critiques of Smith's account of the division of

7. See Freyssenet 1979.

8. I insist upon the two terms 'immaterial' and 'cognitive' because the concept of immaterial labour, when used by itself to characterise the present change in labour, is, in my opinion, insufficient and imprecise. The essential trait of the present transformation in labour is not limited to its many immaterial dimensions or, more precisely, those of its products. It can above all be found in the reappropriation of the cognitive dimensions of work by living labour, with respect to all material and immaterial activity. 
labour. The polarisation of knowledges and the split between intellectual and material tasks are no longer considered a natural modality and a necessary consequence of the development of the productive forces. On the contrary, these tendencies result from the very specific historical modalities by which capital renders technical progress endogenous through the subordination of the labour process (in the sense of the production of use-values) to the valorisation process (production of exchange-values and means of extraction of surplus-value). ${ }^{9}$ The development of the division of labour begins with the conflictual relation of capital and labour established in the dynamic of technical and organisational innovation. For example, Marx locates the struggle for the reduction and the regulation of the working day (using the example of conflicts over wages) at the centre of the logical-historical passage that, in the first book of Capital, leads from the notion of absolute surplus-value to that of relative surplus-value.

Of even greater importance is Marx's insistence on one specific dimension of this complex dialectic of conflict and innovation: the conflict regarding the control of the 'intellectual powers of production'. From this, a conception of technical progress arises that is not limited to underlining the impact of it on the productivity of labour and economic efficacy. Instead, it places the accent on the relations between knowledge and power which have structured the evolution of the technical and social division of labour. ${ }^{10}$ The struggle over the control of the 'intellectual powers of production' is explained by the tendency according to which, under capital, the development of science applied to production proceeds at an equal rate with the expropriation of the knowledges of workers. However, it also explains the resistances that this type of technical progress encounters amongst wage-earners and, thus, the counter-tendencies that can give rise to a recomposition of knowledge and of collective labour. In effect, if technical progress in its capitalistic form allows the expropriation of the traditional knowledge of the worker, the labour process remains irreducibly conflictual. In such a way, a new type of knowledge tends incessantly to reconstitute itself at the level of the capitalist development of the technical and social division of labour. ${ }^{11}$

9. This approach enables us to understand technology as a materialised social relation and to comprehend that it is not the level of technological development considered in itself which determines the application of a determinate form of organisation of labour but, rather, its adequacy to a determinate moment as support for the extraction of surplus labour.

10. To use the terms by which Smith defines the double determination of the division of labour in the factories and in market-driven society.

11. See Salama and Hai Hac 1992. In addition, it is important to remember that the irreducible dimension of workers' knowledge was also apparent in the big Fordist factories in the fundamental difference between prescribed tasks and the reality of workers' labour. Without this difference, qualified by the 'paradoxical implication' of the mass worker, the Fordist assembly line would never have been able to function. 
Thus, the analysis of technical progress as an expression of a relation of forces concerning knowledge is everywhere present in Marx's work and allows an alternative reading of some crucial aspects of his thought.

The conflictual dynamic of the relation of knowledge to power occupies a central position in the explanation of the tendency of the increase of the organic and technical composition of capital. This tendency, Marx writes, results from the way the system of machines arises in its totality: 'This road is, rather, dissection [Analyse] - through the division of labour, which gradually transforms the workers' operations into more and more mechanical ones, so that at a certain point a mechanism can step into their places. ${ }^{\text {' }}{ }^{12}$

In effect, the tendency of the rise in the technical and organic composition of capital translates

into the system of values a fundamental tendency of the capitalist mode of production: the increasing separation of producers and of means of production at the level of the forces of production, or more exactly, at the level of the relations of expropriation... [of the knowledges of the working class], the location of which is the labour process.... This relation constitutes a 'struggle of class in production'... whose outcome is the control of the labour process and therefore of the production of relative surplus-value, the control of which is initially deposited in the craftsman and later the skilled labourer. ${ }^{13}$

We will not dwell at length here on the debate on the tendency of the falling rate of profit. What we are concerned with, instead, is to underline how, if the accent is placed on the qualitative dynamic of the relation of knowledge to power that structures the tendency of the rise in the organic composition of capital, it becomes possible to hypothesise another form of structural crisis. Such a crisis is articulated on the basis of a different logic from that of the traditional Marxist approach in terms of value and the overaccumulation of capital. It supposes, rather, a qualitative change, at the level of the technical composition of capital and of the social labour process. This overturns the relation of subordination of the living knowledge incorporated in labour-power to the dead knowledge incorporated in fixed capital. It is an overturning in the relation of living knowledge/dead knowledge that could be characterised as the 'tendential fall of the capital's control of the division of labour. ${ }^{14}$ The numerous elements that lead to this hypothesis of a superior level of 'great crisis' of industrial capitalism are evoked throughout Marx's work. However, in our opinion, it is above all in the

12. Marx 1973, p. 703.

13. Lipietz 1982, pp. 204-5.

14. See Vercellone 1999. 
Grundrisse that it is explicated, in particular, in the passages on the 'Fragment on Machines' (in Notebook VII). Here, Marx announces the advent, after the stages of formal and real subsumption of labour to capital, of a new stage of development of the division of labour. It is here that Marx speaks of the 'general intellect' in order to characterise the impact of this change on the division of labour and on technical progress. In such a way, he anticipates certain key aspects of an historical conjuncture in which the productive value of intellectual and scientific labour becomes dominant and knowledge re-socialises everything, becoming the principal productive force. ${ }^{15}$ It is for this reason that a return to Marx's notions of formal and real subsumption and of the 'general intellect', and to the evolution between these forms of the technical and social division of labour, may be of great interest for advancing the notion of a post-Smithian twenty-first century. ${ }^{16}$

\section{The lessons of the phase of formal subsumption for an interpretation of the crisis of industrial capitalism}

Marx uses the notions of formal subsumption, real subsumption and the general intellect in order to qualify, in their logical-historical succession, profoundly different mechanisms of subordinating the labour process by capital (and of the type of conflicts and of crisis which they generate). In this investigation, Marx moves from the stage of the formal subsumption of labour by capital, in which capital subordinates a social and technical division of labour that, in the beginning, 'is distinguished only formally from the earlier modes of production. ${ }^{17}$ Capital subsumes, essentially by means of the expedient of mercantile and

15. See Negri 1992.

16. 'Post-Smithian' insofar as we can retrospectively affirm that Fordist growth has, in many respects, represented the historical outcome of the industrial model, the essential traits and tendencies of which Adam Smith anticipated in the famous examples of the manufacture of pins. On the one hand, thanks to the association of Taylorist principles and mechanisation, labour-power is integrated with an always more complex system of utensils and machines. Productivity can be now represented as a variable whose determinants no longer take into any consideration the knowledge of the workers. In this sense, the Smithian representation of the technical division of labour, characterised by the parcelisation of labour and the separation of the tasks of planning and execution, finds a sort of historical fulfilment. Knowledge and science applied to production are separated from collective labour and, as Smith announced, have become 'like every employment, the principal or sole trade and occupation of a particular class of citizens' (Smith 1970, p. 10).

17. 'I call the form which rests on absolute surplus-value the formal subsumption of labour under capital because it is distinguished only formally from the earlier modes of production on the basis of which it directly originates (is introduced), modes in which either the producers are selfemployed, or the direct producers have to provide surplus labour for others. The compulsion exerted there, i.e. the method of extracting surplus labour, is of a different kind. The essential features 
monetary relations, a labour process which pre-exists it and in which the cooperation of workers does not require mechanisms of capitalist direction of production. Co-operation in labour relations remains technically autonomous with respect to capital. The control of the labour process and the modalities of appropriation of the surplus are founded, in the first instance, on mechanisms external to the directly productive sphere, as, for example, in the model of the putting-out system. Bearing in mind the autonomy of productive social cooperation (of the qualitative preponderance of the variable component over that of constant capital, Marx would say), the compulsion to surplus labour (under the form of wage-labour and/or of autonomous craft labour) results essentially from the mercantile subordination of the worker which forces him to sell his labour-power (lacking other means of access to money and/or to non-mercantile appropriation of the means of subsistence).

The contradiction between the relation of monetary dependence of the wageworkers in the process of circulation and their autonomy in the regulation of the labour process is one of the key characteristics of the formal subsumption of labour to capital. ${ }^{18}$ From this contradiction derives, as noted, the crucial position that the policies of de-socialisation of the economy (enclosures, poor laws, etc.) had in the long and difficult process of gestation of the first industrial revolution. Lacking a real compulsion materialised in the productive forces, such policies aim to fix the workforce and to emphasise, in order to render it really efficacious, the monetary compulsion of wage-labour. These policies - whose logic are similar to the neoliberal strategies mobilised following the crisis of Fordism were, in that period, a necessary preamble to the process of the expropriation of traditional knowledges that formed the basis for the subsequent passage from

of formal subsumption are these: 1) the purely money relation between the person who is appropriating the surplus labour and the person who provides it; to the extent that subordination arises, it arises from the particular content of the sale, not from a subordination pre-posited to the sale... 2) Something implied by the first relation - for otherwise the worker would not have to sell his labour capacity - namely the fact that the objective conditions of his labour (the means of production) and the subjective conditions of his labour (the means of subsistence) confront him as capital, as monopolised by the buyer of his labour capacity... As yet there is no difference in the mode of production itself. The labour process, seen from the technological point of view, continues exactly as it did before, except that now it is a labour process subordinated to capital' (Marx and Engels 1975-2005, Volume 34, pp. 93-4, translation modified).

18. Formal subsumption also shows the ambiguity of the historical process of formation of free wage-labour. In effect, the possibility of disposing of its labour-power constitutes one of the stages of the historical movement of emancipation of dependent labour (in a wide sense of the term) in its incessant attempt to escape from such a condition. At the same time, free wage-labour corresponds to a process of expropriation which generates the progressive proletarianisation of the rural population and of craftsmen ('precarisation', as we would say today), making economic compulsion to the wage relation the social norm of access to labour and to the wage. 
formal subsumption to real subsumption. In reality, the historical stage of formal subsumption presents numerous analogies with the configuration of the relation of capital to labour that arose following the crisis of Fordism.

Such an approach provides us many lessons for grasping the specificity of, and what is at stake in, the current transformations of the division of labour. This is the case, above all, if Marx's contribution is combined with that of Braudel, the historian of the long dynamic of capitalism. A first lesson, following Braudel, is that capitalism is 'an old story which precedes and goes beyond the first industrial revolution'. The industrial form of capitalism constitutes nothing but a stage in its history. Far from being born in the industrial revolution, capitalism developed for a long phase of its history without accelerating technical progress and on the basis of forms of surplus appropriation essentially indirect and external to the sphere of production - at least in the countries at the centre of the capitalist world system. ${ }^{19}$ The essential feature of capitalism is, in fact, linked to the extreme flexibility of its mechanisms of domination, to its capacity to be eminently adaptable and, therefore, non-specialised. ${ }^{20}$

Such flexibility emerged from the general formula of capital (M-C-M') and explains the type of relation which capital entertains with the sphere of production. From the standpoint of accumulation, monetary capital invested at the beginning of the cycle $(\mathrm{M})$ is characterised by its flexibility, liquidity and freedom of choice. (C) is nothing but an interruption, in the ideal short circuit (M-M') which introduces (under the form of mercantile capital just as that of productive capital) materialisation, rigidity and uncertainty. ${ }^{21}$ Such uncertainty is consequently greater for capital engaged in production. Before confronting the realisation of surplus-value, it must abandon itself to the risks linked to the direct management of the organisation of labour. The extension of such uncertainty depends on socio-institutional factors which support the regulation of the wage relation and, more generally, all of the other forms of dependent labour. Among these factors, the principal factor is undoubtedly the extent of domination of technology and of the knowledge on which the functions of direction and of capitalist control of the labour process rely. As Arrighi demonstrates, Marx's formula suggests that

the capitalist agents do not invest money in the particular productive combinations of output/input as an end in itself, with the consequent loss of flexibility and of freedom of choice which this entails. On the contrary, they consider the productive

19. See Amin 1975.

20. See Braudel 1981-4.

21. On this subject see Arrighi 1996, pp. 22-3. 
investment as a means for assuring themselves in the future an even greater flexibility and freedom of choice. If such anticipation of a greater freedom of choice in the future is negative or systematically unsatisfactory, capital tends to return to more flexible forms of investment, above all in its money form. ${ }^{22}$

We suggest that the precariousness of the forms of capitalistic control of the organisation of labour helps to explain, in the centuries before the industrial revolution, the slowness with which capital penetrates the sphere of production and the great difficulties encountered from the expansion of the system of concentrated manufacture. The force that regulates the labour process, both in terms of the control of working methods and the intensity of labour, remains incorporated in the living knowledge of the collective worker. In such a way, 'since handicraft skill is the foundation of manufacture, and since the mechanism of manufacture as a whole possesses no objective independent framework, apart from the labourers themselves, capital is constantly compelled to wrestle with the insubordination of the workmen.'23

For this reason, until the arrival of the mechanisation of the process of production, the system of 'concentrated manufacture' experienced only a weak development and the merchant entrepreneur, rather than turning himself into a captain of industry, continued to privilege the model of the putting-out system. This historical example could reveal a more general tendential law of the dynamic of capital accumulation. That is, the more the organisation of the cycle of production appears to be founded on a productive co-operation autonomous from the function of the direction of capital and/or traversed by a strongly conflictual dynamic, the more capital will tend to privilege indirect forms of domination of production and of the mechanisms of surplus appropriation realised by means of the sphere of monetary and financial circulation. This interpretative paradigm, which draws together forms of the division of labour and forms of capital accumulation, can also help to explain the historical alternation of the different phases of accumulation of capital: there would thus be phases characterised by forms of productive, financial and commercial accumulation. In this sense, in order to place the crisis of industrial capitalism in an historical perspective, another lesson offered by the stage of formal subsumption is that also today capital could extend without problems 'to rid itself once again of its directly productive forms... and attempt to appropriate surplus, extracting it from other relations. ${ }^{24}$

22. Arrighi 1996, p. 22.

23. Marx and Engels 1975-2005, Volume 35, p. 373 (translation modified).

24. Dockès and Rosier 1983, p. 14. 
On the other hand, it is precisely from the standpoint of the history of the 'world-economy' that Braudel has furnished us with the elements for a stimulating interpretation of the meaning of the crisis of Fordism. ${ }^{25}$ The latter, according to Braudel, even though presenting in toto certain characteristics proper to a descending phase of a Kondratieff long wave, represents a historical rupture more profound than that diagnosed by the neo-Schumpeterian interpretations of long cycles. It would be a case of an inversion of tendency, which would once again put into question the very logic of development of the form of capitalism that arose with the first industrial revolution. The exhaustion of the propulsive power of industrial capitalism would favour the true capitalisme du sommet, in Braudel's sense, privileging once again the indirect instruments of domination proper to mercantile and financial capitalism. The unification of the three cycles of capital in differentiated moments of a single cycle under the aegis of productive capital will be nothing other than the dominant expression of a transitory phase of the history of capitalism. ${ }^{26}$ From this perspective, we could add that the genesis of the current process of financialisation maintains a close relation with the conflictual transformations of the division of labour determined by the crisis of Fordism. Financial globalisation could also be interpreted as capital's attempt to render its cycle of valorisation ever more autonomous from a social labour process which it no longer subsumes in real terms. Thus, we have an interpretative paradigm that is of even greater interest if we reconnect this Braudelian approach of the long dynamic of capitalism with Marx's hypothesis of the general intellect and of a crisis of the Smithian division of labour inherited from industrial capitalism.

\section{Real subsumption and the logic of the industrial division of labour}

The process that leads to the real subsumption of labour by capital begins with the first industrial revolution. It is based on a series of tendencies which flow into Fordism: the progressive separation of intellectual and manual labour, the separation of conceptual and material tasks, and the polarisation of knowledges and the parcelisation of labour which determine the dynamic of technical and organisational change by means of which capital progressively affirms its control of the product and the labour process.

It must be noted - such an element is very important for comprehending one of the aspects of the current crisis - that these tendencies of the division of labour and of technical progress rely on the establishment of a social institution central 
to the dynamic of industrial capitalism: the social norm that establishes the time of immediate labour (directly dedicated to a productive activity) the principal unit of measure and the source of the wealth derived from the development of the productive power of human labour. In effect, before the industrial revolution, the distinction between labour and non-labour was almost absent (in a universe in which multi-activity and the versatility of individuals still dominated). Labour (activity in general) was the measure of a time not measured by the clock and the chronometer in terms of its efficacy. Following the development of the capitalist enterprise, 'this relation is inverted: time becomes the measure of labour ${ }^{27}$ and, consequently, the norm of valuation of the production and distribution of wealth. It is with the assertion of the authority of the factory system that time becomes the measure of labour and the time of labour emerges as a socially central factor. The time of the clock and the chronometer as means for quantifying the economic value of labour and prescribing its operative modes thus represents, together with machinery, the essence of the economic and cultural transformation of labour determined by the industrial revolution. It is such successive forms of the economy of time that forge the logic of technical progress which, on the basis of the association of the principles of Taylorism and of mechanisation, will flow into Fordism. In such a way, labour becomes ever more abstract, not only under the form of exchange-value, but also in its content, emptied of any intellectual and creative quality. ${ }^{28}$

The subsumption of the worker to capital becomes real when it is imposed inside the production process and no longer only outside it. The subsumption of labour to capital is now imposed as an imperative dictated in some way by technology and by the character, now external to the collective worker, of the mass of knowledges which structure the division of labour and permit the co-ordination of productive co-operation. The compulsion to wage-labour is no longer merely of a monetary nature, but also of a technological nature, rendered endogenous by technical progress. In such a way, the individual labour-power of the producer, increasingly reduced to a simple living appendage of the system of machines, 'now... refuses its services unless it has been sold to capital.29 From this point of view, the dynamic of development of real subsumption needs to be understood in the two-fold dimension ${ }^{30}$ that characterises this concept:

27. See Roger Sue, cited in Guedj and Vindt 1997, p. 44.

28. See Negri 1991 and 1992.

29. Marx and Engels 1975-2005, Volume 35, p. 365.

30. In the interdependence between these two aspects of the (technical and social) division of labour, we find again the presuppositions of a model à la Smith-Young, with growth endogenous to technical progress that is understood to be specific to industrial capitalism. 
(a) At the level of the technical division of labour, it designates the tendency according to which capital renders the exigencies of control of labour-power endogenous to the dynamic of technical and organisational change.

(b) At the level of the social division of labour, real subsumption designates the tendency of industrial capitalism to incorporate the totality of society, by means of the generalisation of the wage relation and of exchange-value, and the upsetting of the conditions of existence of wage-labour. This dynamic is translated in part in the foundation of a norm of consumption integrated into capital accumulation. Nevertheless, it also generates a conflictual process that will lead to the socialisation, on the part of the state, of certain costs of the reproduction of labour-power. In this perspective, with the development of the institutions of the welfare state, mass education is established, as well as the tensions that progressively emerge within this educational system. This has, in principle, among its chief tasks that of reproducing and justifying a hierarchy of knowledges corresponding to that of the existing social classes.

The 'democratisation' (although partial) of education is one of the factors at the origin of the diffusion of knowledges and of the crisis of the first dimension of real subsumption.

In summary, the dynamic of economic and social transformation which leads from formal to real subsumption allows us to highlight the historical process by means of which the class of industrial capitalists was formed on the model of the working class (and against it), and was led to integrate the conflicts within the conditions of capital accumulation, inasmuch as it is a dynamic spur and macro-economic stabiliser of growth. ${ }^{31}$ To read the structure of capital in a given moment signifies in large measure to reconstruct, in reverse, the history bequeathed to us by the incessant struggle of wage-labourers for the reappropriation of knowledges and for the emancipation from the economic compulsion of wage-labour. Such a dialectic of conflict-innovation-development has played a driving role in the succession of different productive paradigms which lead from the first industrial revolution to Fordism. The latter, from the point of view both of the norms of production and of consumption, has constituted, under many aspects, the realisation of the historical tendency to real subsumption. This is so even if it contained contradictions (subjective and objective) prone to lead to its crisis and to determine the passage to a new postindustrial stage of the division of labour.

31. Negri 1991, and 1992; and Tronti 1966. 
In effect, nothing renders the tendency to the expropriation of knowledges and to the deepening of real subsumption irreversible. It is at the level of a collective reappropriation of knowledges, which took effect at the most general level of the division of labour determined by Fordism, that we can best understand the role played by the development of mass education in the formation of a diffuse intellectuality and in the emergence of a new division of labour. Such an evolution seems, in effect, to realise certain of Marx's intuitions regarding the general intellect.

\section{The originality of the Grundrisse: the general intellect as sublation of the real subsumption of labour to capital ${ }^{32}$}

In the first book of Capital, Marx limits his analysis of the transformations of the division of labour to the stages that lead to simple co-operation and from manufacture to modern industry. This logico-historical schema could be mistakenly considered a judgement on the insuperable character of the tendency to real subsumption. This interpretation of Capital will favour a reading of the limits of capitalist development of the productive forces that places the accent on the anarchy of the market to the detriment of the contradictions generated by the conflicts traversing the capitalist division of labour. Nevertheless, in all of Marx's work, the critique of the capitalist division of labour and the analysis of the conflicts of which it is the fulcrum represent the heart of his approach to the crises and the dynamics which would have led capital to work 'towards its own dissolution in as much as it is the form dominating production. ${ }^{33}$ This problematic, moreover, is confronted in the first book of Capital when Marx underlines how the historical stake represented by the legal reduction of labour time is indissolubly linked to a more general struggle for the socialisation of access to knowledge. One thinks of how Marx welcomed, together with the promulgation of the first law regulating the working day, the conquest of the bases of a generalised elementary public education. 'That first and meagre concession wrung from capital ${ }^{134}$ was, according to Marx, nothing other than the point of departure for a conflictual dynamic for the abolition of 'the present system of education and division of labour, which beget hypertrophy and atrophy

32. The title of this section also intends to underline a major difference between our interpretation and the readings of the Grundrisse that tend always to lead the category of the general intellect back into the perspective of the logic of real subsumption.

33. Marx 1973, p. 699. In The German Ideology, for example, communism as 'the real movement which abolishes the existing state of affairs' was defined in terms of an historical process tending toward the suppression of the capitalist division of labour (Marx and Engels 1975-2005, Vol 5, p. 37).

34. Marx and Engels 1975-2005, Volume 35, p. 489. 
at the two opposite extremities of society. ${ }^{35}$ In his reading of the development of the capitalist division of labour, Marx recognised a central role for the struggles over the socialisation of education whose ends (the 'abolition of the old division of labour') are 'diametrically opposed' to the dynamic of real subsumption. ${ }^{36}$ In this sense, it is possible to affirm that, for Marx, the development of mass education was one of the essential conditions which would have permitted wagelabourers to accumulate a 'technological, theoretical and practical' knowledge adequate to the level attained by the capitalist development of the social and technical division of labour and, at the same time, to undertake its supersession.

In reality, it is actually under the pressure of a conflictual dynamic and not only due to the necessity to adapt the system of education to the exigencies of the labour market, that the state was led progressively to develop public education, socialising a part of the costs of the reproduction of labour-power beyond the logic of the market. Mass education and the development of a diffuse intellectuality make the educational system a central site for the crisis of the Fordist wage relation. ${ }^{37}$ The key role attributed to the theme of the development of a 'socialised and free' sector of education in the conflicts concerning the control of 'intellectual powers of production' is, therefore, an essential element of Marx's elaboration of the notion of the general intellect. ${ }^{38}$ The establishment of a diffuse intellectuality is configured as the necessary historical condition, even if, in the Grundrisse, this reference is implicit and, in some cases, concealed by a dialectical approach to the evolution of the division of labour that privileges the analysis of structural changes instead of the institutions and the subjects which could have originated these transformations. ${ }^{39}$

35. Ibid.

36. Ibid. This vision anticipates the Gramscian concept of 'hegemony' and the problematic of its conquest by the wage-labourers.

37. The social crisis of the Fordist wage was manifested in a multiplicity of conflicts that led to a destabilisation of the Fordist organisation of work and the institutions of disciplinary society. Therefore, it is the refusal of the scientific organisation of labour that largely explains the falling rate of profit and the social exhaustion of the Taylorist gains in productivity through which the Fordist crisis has been manifested since the end of the 1960s. If, in the scope of this article, we insist above all upon the formation of a diffuse intellectuality, it is for two main reasons. First, it is the new intellectual quality of labour-power that has led to the reaffirmation of the cognitive dimensions of labour. It is this new quality that explains the change from the Taylorist model to a model of communicative co-operation characteristic of the cognitive division of labour. Second, the crucial place that the development of a diffuse intellectuality has with respect to the realisation of Marx's notion of the general intellect (the principal subject of this paper).

38. From this point of view, our interpretation diverges from that of Paolo Virno, according to which Marx identifies the general intellect with fixed capital in toto, in contrast to the way that the same general intellect presents itself as living labour (cf. Virno 1992).

39. In the passages of Theories of Surplus-Value dedicated to Hodgskin, we find a first draft of the 
We will, therefore, follow the principal stages of Marx's argumentation through which, in the Grundrisse, the advent of an economy based upon the diffusion and the driving role of knowledge is announced.

At the beginning of his analysis (Grundrisse, Notebook VII), Marx analyses the implications of real subsumption, which reduces the labour of the worker to a 'mere abstraction of activity.' ${ }^{4}$

Nevertheless, in the Grundrisse, contrary to what occurs in the first book of Capital, Marx does not stop here, but continues to consider the dynamics of the division of labour that are able to carry out a recomposition of science and of the collective worker. From this perspective, he suggests how the deepening of the logic of real subsumption can create certain conditions favourable to a collective reappropriation of knowledges insofar as 'living labour' is able to reconvert a part of its surplus labour into free time.

In its incessant attempts to economise on the time of labour, 'capital - quite unintentionally - reduces human labour, expenditure of energy, to a minimum. This will redound to the benefit of emancipated labour, and is the condition of its emancipation. ${ }^{41}$ In effect, 'The saving of labour time [is] equal to an increase of free time, i.e. time for the full development of the individual, which in turn reacts back upon the productive power of labour as itself the greatest productive power. ${ }^{32}$ In other words, the reduction of direct labour-times necessary for production can allow the liberation of times dedicated to free time and to education, which are indispensable conditions for liberated labour. Whether or not these potentials are realised depends to a great extent on the degree of socialisation of education, that is, its transformation into a type of education that favours the metamorphosis of the parcelised worker of Fordism into the immaterial, polyvalent worker 'fit for a variety of labours, ready to face any change of production, and to whom the different social functions he performs,

general intellect when Marx writes: 'accumulation is nothing but the amassing of the productive powers of social labour, so that the accumulation of the skill and knowledge (scientific power) of the workers themselves is the chief form of accumulation, and infinitely more important than the accumulation - which goes hand in hand with it and merely represents it - of the existing objective conditions of this accumulated activity' (Marx and Engels 1975-2005, Volume 32, p. 399). Marx underlines that Hodgskin, in his thesis on the unproductivity of capital 'underestimates somewhat the value which the labour of the past has for the labour of the present'. However, this affirmation of the primacy of subjective conditions (skill and knowledge) over objective conditions influenced without doubt his elaboration on the meaning and role of the general intellect.

40. Marx 1973, p. 699.

41. Marx 1973, p. 701.

42. Marx 1973, p. 711. 
are but so many modes of giving free scope to his own natural and acquired powers. ${ }^{43}$

It is important to emphasise that the point of departure of the analysis of the general intellect refers to a preliminary transformation of the intellectual quality of living labour, or to the education of a diffuse intellectuality. This new configuration of the relation of capital to labour gives an impulse to the beginning of a new phase of the division of labour in which

the development of fixed capital indicates to what degree general social knowledge has become a direct force of production, and to what degree, hence, the conditions of the process of social life itself have come under the control of the general intellect and been transformed in accordance with it. ${ }^{44}$

This mutation re-opens the discussion regarding the principal pillars on which the political economy of industrial capitalism is based.

From the moment in which knowledge and its diffusion is affirmed as the principal productive force, the relation of domination of dead labour over living labour enters into crisis and 'Labour no longer appears so much to be included within the production process; rather, the human being comes to relate more as watchman and regulator to the production process itself. ${ }^{35}$ Inside this new situation, the attempt to distinguish the productive contributions respectively of capital and of labour (as the neoclassicists do, separating the parts of the different 'factors of production' in the product) definitively loses all of its foundations. The principal 'fixed capital' becomes 'man himself', in Marx's words, ${ }^{46}$ which anticipates a logic of development driven by knowledge with an approach much more rich and complex than that of the reductive representations of the 'new' theories of endogenous growth, as we will see.

This transformation involves two other key consequences:

(a) The law of value founded on the measure of abstract labour-time immediately dedicated to production enters into crisis.

In this transformation, it is neither the direct human labour he himself performs, nor the time during which he works, but rather the appropriation of his own general productive power, his understanding of nature and his mastery over it by virtue of his presence as a social body - it is, in a word, the development of the

43. Marx and Engels 1975-2005, Volume 35, p. 489.

44. Marx 1973, p. 706.

45. Marx 1973, p. 704.

46. See Marx 1973, p. 711. 
social individual which appears as the great foundation-stone of production and of wealth.... As soon as labour in the direct form has ceased to be the great well-spring of wealth, labour time ceases and must cease to be its measure, and hence exchangevalue [must cease to be the measure] of use-value. ${ }^{47}$

Inside these transformations, labour, particularly in the form of knowledge, remains nevertheless the principal source of the creation of wealth, but it can no longer be measured on the basis of labour time directly dedicated to production.

(b) Secondly, in that which we could call the historical passage from the timevalue of labour to knowledge-value, the traditional opposition between labour and non-labour loses any foundation in as much as 'direct labour time itself cannot remain in the abstract antithesis to free time... [free time] which acts upon the productive power of labour as itself the greatest productive power. ${ }^{48}$

After formal and real subsumption, the historical emergence of the figure of the collective worker of the general intellect can be interpreted as a point of origin of a new stage of the division and of a very extensive crisis of transition marked by two contradictions:

i) The first results from the contradiction between the mutation of the notion of productive labour bound to an economy founded on the driving role of knowledge, and the logic of capital for which 'the tendency is always, on the one side, to create disposable time, on the other, to convert it into surplus labour. ${ }^{49}$ In short, the crisis of the law of value does not signify its disappearance in so far as capital continues to maintain it vigorously in a forced manner, as wretched base' of the measure of wealth and norm of its distribution. At the same time, extending Marx's thought, it can be affirmed that the crumbling of the traditional frontiers between labour and non-labour related to the ever more immaterial and intellectual character of labour leads to an extension of the mechanisms of extraction of surplus-value to the totality of social times which participate in social production.

ii) The second derives from the ascertainment that, in the general intellect, when knowledge is diffused, 'it no longer has proprietors' ${ }^{50}$ (contrary to what the

47. Marx 1973, p. 704.

48. Marx 1973, p. 711.

49. Marx 1973, p. 708.

50. Gorz 1997, p. 18. 
theoreticians of endogenous growth posit). Capital is no longer able to construct a new 'objective independent framework' by means of a further deepening of the Smithian logic of the capitalist division of labour that opposes conception to execution. In this way, the subsumption of labour is once again formal in the sense that it is based essentially on the relation of monetary dependence of the wage-labourer inside the process of circulation.

This interpretative schema also allows us to comprehend that the precariousness of the conditions of remuneration and of employment that characterise cognitive capitalism can in no way be considered an unavoidable economic logic. The historical meaning of this tendency consists, rather, in forcefully making reemerge the primary nature of the wage relation: that of being a monetary bond which makes wage-labour the condition of access to money; that is, an income made to depend upon the anticipations of capitalists that determine the volume of production and employment. ${ }^{51}$

Finally, the notion of the general intellect provides us with many elements to analyse the factors at the base of the crisis of industrial capitalism. These highlight the new sources of wealth (and of growing output) in a model that is appropriate to cognitive capitalism. Among these elements, we shall mention the following: i) the crisis of the model of social and technical division generated by the first industrial revolution; ii) the role and the diffusion of knowledge which obeys a co-operative social rationality which escapes the restrictive conception of human capital; iii) re-opening the discussion of immediate labour as the principal productive time and the impossibility of maintaining the direct time of labour as measure of productivity and of access to income; iv) the concomitant passage from a theory of time-value of labour to a theory of knowledge-value where the principal fixed capital is man 'in whose brain exists the accumulated knowledge of society'; ${ }^{52} \mathrm{v}$ ) sovereignty, 'violence' and the primordial character of money in the institution of the wage and mercantile order; vi) the necessity of recognising, against the logic of capital, the increasingly collective nature of technical progress, in order to place it at the service of the increase of effective liberty of individuals and the 'diversity of existence', and to affirm the primacy of use-value over exchange-value.

51. It is equally important to note that the crisis of real subsumption at the level of the labour process drove capital to attempt to subject and prescribe the worker's subjectivity itself according to the logic of a society of control.

52. Marx 1973, p. 711 (trans. modified). 


\section{Conclusions. Cognitive capitalism versus the general intellect: tensions and new forms of antagonism}

The Marxian category of the general intellect bestows on us an extremely rich legacy for comprehending the foundations and the contradictions of the new division of labour born from the crisis of industrial capitalism and the advent of cognitive capitalism.

In synthesis:

i) The affirmation of the figure of the general intellect corresponds to a structural crisis of industrial capitalism itself. It indicates a superior level of 'great crisis, half way between regulationist notions of a 'crisis of a mode of development' and 'crisis of the mode of production itself. ${ }^{53}$ It is a case of a crisis of mutation that challenges the tendencies that support the division of labour and the accumulation of capital, departing from the first industrial revolution. The industrial configuration of capitalism (and the modes of development which marked its history) has constituted only a specific phase in the dynamic of the longue durée of capitalism.

ii) For Marx, the ascent of cognitive capitalism cannot be explained through a technological determinism that understands the new technologies and the knowledge incorporated in fixed capital as the principal motor of the passage to a new division of labour. On the contrary, the essential dimension of this mutation is found in the conflicts that have led to a new qualitative preponderance of the knowledges of living labour over knowledges incorporated in fixed capital and in corporate organisation. From this point of view, knowledge cannot be assimilated either to capital (as in the theory of human capital), or constituted in a supplementary factor of production (independent from capital and from labour, as some interpretations of cognitive capitalism assume).$^{54}$ Knowledge and education are nothing but the means of expression and creation of labour. These are subjective conditions of production that characterise the use-value of labour-power.

53. The notion of a crisis of 'a mode of development' indicates in the terminology of the French regulation school (Aglietta, Boyer, Lipietz, Petit) a great crisis of the transformation of the dynamic of industrial capitalism. The theory of regulation has not, however, considered in its conceptual apparatus the hypothesis of a superior level of crisis, which we could define with the concept of a 'great crisis of the historical system of accumulation of industrial capitalism'. For a critique of the regulationist approach and a presentation of the concept of 'crisis of an historical system of accumulation', see Vercellone 2003a and Paulré 2004. For a presentation of the theory of regulation, see Boyer 1986.

54. Husson 2001; and Rullani 2000. 
iii) The capitalism of the general intellect, far from eliminating contradictions and antagonisms, displaces them and, to a certain extent, increases their significance. Following Marx, the new terms of the relation of capital to labour in cognitive capitalism can be characterised in this way.

iv) The traditional opposition between dead labour/living labour, proper to industrial capitalism, gives way to a new form of antagonism, that between the dead knowledge of capital and the 'living knowledge' of labour. Thus, 'The modern mutation could be summarised... in a formula: we pass from the static management of resources to the dynamic management of knowledges. Productive science is no longer "encapsulated" in the rigid logic incorporated in machines. 55 On the other hand, inside the enterprise just as in society, the mobilisation and the co-operation of collective knowledges is increasingly fundamental, the only elements able to release and to control a dynamic of accelerated change.

v) This displacement of the terms of antagonism corresponds to a subsumption of labour to capital which is, once again, essentially formal from the point of view of the labour process. However, differently from the practical knowledges of the old craftsmen, the living knowledges of diffuse intellectuality today cannot be 'expropriated' by a deepening of the Smithian logic of the division of labour that found its summit in Taylorist and Fordist principles of organisation of labour. Such a type of expropriation could not be effected other than at the price of a lowering of the general level of education of the workforce, a level which is recognised to be the source of the wealth of nations and the competitiveness of enterprises. The resurgence of tensions regarding self-determination in the organisation of labour and the social ends of production depends on the reaffirmation of the autonomy of living knowledge.

vi) In the activities in which the cognitive and immaterial dimension of labour is dominant, we witness a destabilisation of one of the structuring conditions of the wage relation, that is to say, the renunciation - compensated by the wage - by the workers to any claim on the property of the product of their labour. In cognitive-labour-producing knowledge, the result of labour remains incorporated in the brain of the worker and is thus inseparable from her person. That helps explain, together with other factors, the pressure exercised by enterprises in order to attain a strengthening of the rights of intellectual property and to re-enclose, in a new phase of the primitive accumulation of capital, the social mechanisms at the base of the circulation of knowledge.

vii) Where the time of labour directly dedicated to the production of commodities intensive in knowledge becomes insignificant; or, to put it in the

55. Lorino 1993, p. 82. 
language of neoclassical economic theory, where the marginal costs of reproduction are practically nothing or extremely low, these commodities should be given for free. From this standpoint, the solution searched for by capital is now to advance rights to intellectual property in order to collect monopoly rents. This stratagem corresponds to a situation which contradicts the very principles on which the founding fathers of political economy had theoretically justified private property and the efficiency of a competitive order. In fact, it is now the very creation of property which generates scarcity. It is what Marx (but perhaps even a classical economist like Ricardo) would qualify as an artificial way of maintaining the primacy of exchange-value (which is based on the difficulties of production) against wealth, which is based instead on abundance and use-value, and therefore on free appropriation.

viii) In the capitalism of the general intellect and of value-knowledge, the relation of capital to labour is subjected to two new sources of conflict. On the one hand, precisely due to the crumbling of the traditional frontiers between the sphere of reproduction and that of direct production, the exploitation of the use-value of labour-power expands to the entire social day. ${ }^{56}$ On the other hand, capital's attempt to maintain the permanence of the law of value founded on direct labour-time, despite its crisis, leads to the unemployment and the devalorisation of labour-power. The result of this is the current paradox of poverty within abundance in an economy in which the power and diffusion of knowledges contrasts with a logic of accumulation; and where the frontiers between rent and profit fade, while the new relations of ownership of knowledge obstruct the progress of knowledge through the creation of an artificial scarcity of resources.

In conclusion, in cognitive capitalism the relation of capital to labour is presented as the opposition of two logics, between which it no longer seems possible to re-stabilise a dialectic of struggles/development:

a) on the one hand, the logic of capital accumulation which assumes an ever more parasitic nature through its attempt to enforce the law of value artificially.

56. The need to contrast this extension of exploitation constitutes one of the fundamental elements of the claim for a guaranteed social income (or wage) independent of employment. It is conceived as the remuneration for the totality of social times and for the activities that participate in the creation of value appropriated by enterprises. This guaranteed income should be of a sum sufficient to allow each to have a decent standard of living and to refuse conditions of employment considered as unacceptable. In this way, the guaranteed social income constitutes an instrument to mitigate the monetary compulsion represented by the wage relation and favours the development of activities alternative to the logic of the market and wage-labour. For a more detailed presentation of the proposal of a guaranteed social income, see also: Monnier and Vercellone 2006, Vercellone 2003b and Gorz 1997. 
It does so to the point of blocking the sources themselves of the process of the diffusion and the accumulation of knowledge.

b) On the other hand, the logic of the new figure of the collective worker, the diffuse intellectuality in the brain of which is all of the accumulated knowledge in society' and which holds the totality of prerequisites for a self-management of the conditions and social ends of production..$^{57}$

It is around these contradictions that some of the most essential questions of the critique of the political economy of the knowledge-based economy and of a political project for the overcoming of cognitive capitalism are posited.

\section{Translated by Peter Thomas}

\section{References}

Amin, Samir 1975 [1970], Accumulation on a World Scale, New York: Monthly Review Press. Arrighi, Giovanni 1996, Il lungo XX $X^{\circ}$ secolo, Milan: Il Saggiatore.

Boyer, Robert 1986, La théorie de la régulation: une analyse critique, Paris: La Découverte.

Braudel, Fernand 1981-4 [1979], Civilization and Capitalism 15th-18th, 3 volumes, New York: Harper and Row.

Braudel, Fernand 1982, 'Une rupture plus grave que celle des années trente', (interview with G. Moatti), L'Expansion, October.

Chesnais, François 1994, La Mondialisation du capital, Paris: Syros/Alternatives Économiques.

Dockès, Pierre and Bernard Rosier 1983, Rythmes économiques, crises et changement social: une perspective historique, Paris: La Découverte.

Freyssenet, Michel 1979, La division capitaliste du travail, Paris: Savelli.

Gorz, André 1997, Misères du présent. Richesse du possible, Paris: Galilée.

Guedj, François and Gérard Vindt 1997, Le Temps de travail, une histoire conflictuelle, Paris: Syros.

Husson, Michel 2001, Le Grand bluff capitaliste, Paris: La Dispute.

Lebert, Didier and Carlo Vercellone 2004, 'L'économie de la connaissance et de l'immatériel, entre théorie et histoire: du capitalisme industriel au capitalisme cognitif', in L'économie industrielle en mutation, Cabiers Lillois d'économie et sociologie, Paris: L'Harmattan.

Lipietz, Alain 1982, 'Derrière la crise: la tendance à la baisse du taux de profit', Revue Économique, 33, 2: 204-5.

Lorino, Philippe 1993, 'Être citoyen dans l'entreprise', Manière de Voir - Le Monde Diplomatique, no. 18, May: 82.

Marx, Karl 1973, Grundrisse, tr. M. Nicolaus, Harmondsworth: Penguin.

Marx, Karl and Friedrich Engels 1975-2005, Collected Works (MECW), London: Lawrence and Wishart.

57. In this sense, we could define communism as the real movement by means of which the society of knowledge would liberate itself effectively from the capitalist logic that subsumes it, freeing the potential of emancipation inscribed in an economy founded on the free circulation of knowledge and the democracy of the general intellect. 
Monnier, Jean-Marie and Carlo Vercellone 2006, 'Travail et protection sociale à l'âge du capitalisme cognitif: La proposition de revenu social garanti', in Travailler pour être intégré? Mutations des relations entre emploi et protection sociale, edited by Ai-Thu Dang, Jean-Luc Outin, and Hélène Zajdela, Paris: Editions CNRS.

Negri, Antonio 1991, Marx beyond Marx: Lessons on the 'Grundrisse', translated by H. Cleaver, M. Ryan and M. Viano, ed. J. Fleming, New York: Autonomedia.

Negri, Antonio 1992, 'Interpretation of the Class Situation Today: Methodological Aspects', in Open Marxism, Volume 2, Theory and Practice, edited by W. Bonefeld, R. Gunn and K. Psychopedis, London: Pluto.

Paulré, Bernard 2004, 'Introduction au capitalisme cognitif', Journées d'étude Gres-Matisse-Isys, 25 Novembre, Paris, miméo.

Rullani, Enzo 2000, 'Le capitalisme cognitif: du déjà-vu’, Multitudes, 2: 87-94.

Salama, Pierre and Hai Hac Tran 1992, Introduction à l'économie de Marx, Paris: La Découverte.

Smith, Adam 1970 [1776], The Wealth of Nations, London: J.M. Dent and Sons.

Tronti, Mario 1966, Operai e capitale, Torino: Einaudi.

Vercellone, Carlo 1999, Accumulation primitive, industrialisation et rapport salarial en Italie, Thèse de doctorat, Université de Paris 8.

Vercellone, Carlo 2003a, 'Sens et enjeux de la transition vers le capitalisme cognitif : une mise en perspective historique', Actes des Journées d'étude 'Patrimoine, ordres et dynamique du capitalisme', Université de Reims / INRA-ENESAD de Dijon, 12-13 June.

Vercellone, Carlo 2003b, 'Mutations du concept de travail productif et nouvelles normes de répartition', in Vercellone (ed.) 2003.

Vercellone, Carlo 2004, 'Division internationale du travail, propriété intellectuelle et développement à l'heure du capitalisme cognitive', Géographie, Economie, Société, 6: 359-81.

Vercellone, Carlo (ed.), 2003, Sommes nous sortis du capitalisme industriel?, Paris: La Dispute.

Virno, Paolo 1992, 'Quelques notes à propos du general intellect', Futur Antérieur, 10: 45-53. 